\title{
Vogais Médias Pretônicas na Fala da Região Sudeste: um panorama geo-sociolinguístico
}

\author{
Mid Pretonic Vowels in the Speech of Southeast Region: \\ A GEO-SOCIOLINGUISTIC OVERVIEW
}

\section{Fabiane de Mello Vianna da ROCHA * Silvia Figueiredo BRANDÃO **}

Resumo: Tem-se por objetivo traçar um panorama geo-sociolinguístico do comportamento das vogais médias em contexto pretônico na fala da Região Sudeste, com base em estudos sociolinguísticos realizados em comunidades dos estados do Espírito Santo, Minas Gerais, São Paulo e Rio de Janeiro. Apresentam-se e discutem-se fatores linguísticos e extralinguísticos que condicionam os processos de alçamento, manutenção e abaixamento de timbre na fala de cada comunidade. Demonstra-se que, na fala da Região, em que predominam as variantes médio-altas, fica evidente a relevância da natureza da vogal subsequente para a implementação do processo de harmonização vocálica, quer se trate de alteamento, quer de abaixamento. Do ponto de vista diatópico, observam-se aspectos divergentes que demonstram a maior complexidade da área mineira e, provavelmente, da capixaba, frente às do Rio de Janeiro e de São Paulo, o que pressupõe a existência de diferentes áreas linguísticas, sobretudo no que respeita ao primeiro dos mencionados estados.

Palavras-chave: Vogais médias pretônicas. Região Sudeste. Variação.

\footnotetext{
* Doutoranda pelo Programa de Pós-Graduação em Letras Vernáculas da Universidade Federal do Rio de Janeiro (UFRJ). Contato: fabyufrj@gmail.com.

** Doutora (1988) em Letras Vernáculas pela Universidade Federal do Rio de Janeiro (UFRJ). Professora da UFRJ. Pesquisadora do CNPq. Contato: silvia.brandao@terra.com.br.
} 
Abstract: We aim to trace a geo-sociolinguistic overview of the behavior of pretonic mid vowels in the speech of the Southeast Region, based on variationist sociolinguistic studies carried out in communities of the states of Espírito Santo, Minas Gerais, São Paulo and Rio de Janeiro. We present and discuss the linguistic and extralinguistic factors that affect the processes of raising, maintenance and lowering in each speech community. We demonstrate that, in the speech of the Region, in which the mid-high variants predominate, it is evident the relevance of the nature of the subsequent vowel for the implementation of the vowel harmony process, in the case of raising or lowering. From the diatopic point of view, we observe diverging aspects that demonstrate the increased complexity of Minas Gerais and, probably, of Espírito Santo areas compared to the Rio de Janeiro and São Paulo ones, which presupposes the existence of different linguistic areas, particularly in relation to the first of the mentioned states.

Keywords: Pretonic mid vowels. Southeast Region. Variation.

\section{Introdução}

No Português do Brasil (doravante PB), os fonemas vocálicos variam em número a depender da posição do segmento quanto ao acento. Em sílabas pretônicas, a alternância entre segmentos médios (abertos e fechados) tanto na série anterior quanto na posterior, não implica mudança de significado, retringindo-se ao plano fonético. Nesse sentido, dos cinco fonemas atuantes nessa posição dois deles (/e o/) resultam da neutralização entre as médias abertas e fechadas. Além desse processo, ocorrem o abaixamento e o alteamento que culminam em uma neutralização esporádica e permitem que vogais médias e altas coatuem em certos itens e contextos.

Por seu caráter variável, essas regras são alvo de diversos estudos, que visam, sobretudo, ao estabelecimento de condicionamentos estruturais e sociais para sua aplicação. Enquanto o alteamento tem caráter suprarregional, o abaixamento é mais frequente em determinadas áreas do país, como no Nordeste, em que é dominante, e no Norte, em que concorre com a manutenção do timbre médio-alto. 
Este estudo se propõe a fornecer um panorama geo-sociolinguístico do comportamento das vogais médias pretônicas na Região Sudeste, com base em pesquisas na linha sociolinguística variacionista. A fim de estabelecer um quadro comparativo (seção 5) sobre o alcance do alteamento, manutenção e abaixamento de timbre, focalizam-se (seções 1 a 4), aspectos concernentes a esses processos em alguns falares dos Estados do Espírito Santo, Minas Gerais, São Paulo e Rio de Janeiro.

\section{Um Falar do Espírito Santo}

Sobre o fenômeno variável no Espírito Santo, conhece-se a pesquisa de Celia (2004) a respeito do município de Nova Venécia. Nela, focaliza-se a fala capixaba culta com base em nove informantes do sexo feminino, de nível superior de escolaridade, e se verifica o predomínio de vogais médio-fechadas - [e] e [o], respectivamente com $70 \%$ e $57 \%$ de frequência.

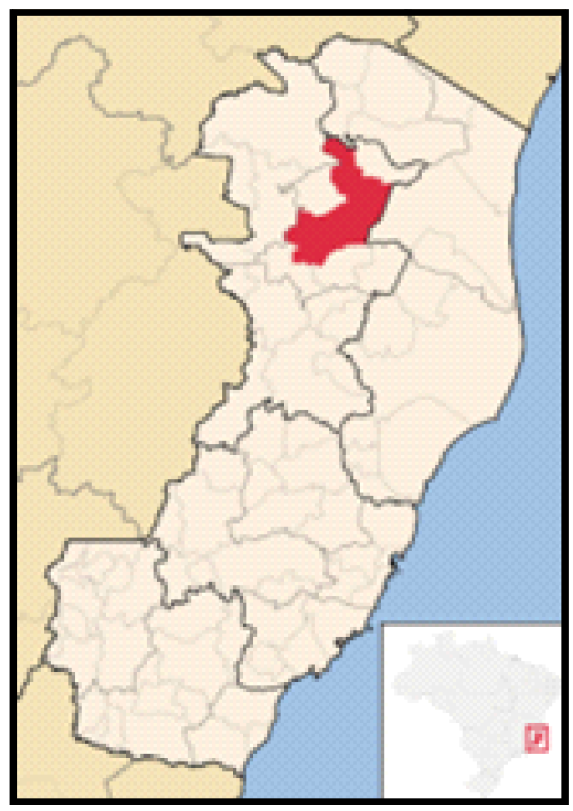

Fonte: pt.wikipedia.org

Figura 1 - Localização de Nova Venécia-ES 
Com base em 5.642 dados, contrapõem-se manutenção a alçamento e retenção a abaixamento e estabelecem-se condicionamentos linguísticos e extralinguísticos para cada um desses processos. A Tabela 1 apresenta os índices encontrados, evidenciando que, embora os dois fenômenos se mostrem pouco influentes na fala da comunidade, em ambas as séries o abaixamento se destaca, em comparação ao alçamento, sugerindo que o dialeto capixaba seja uma área de transição entre os falares do Sul e do Norte do Brasil.

Tabela 1 - Índices de alçamento e abaixamento de médias pretônicas em Nova Venécia-ES

\begin{tabular}{c|c|c|c|c}
\hline \multirow{2}{*}{} & \multicolumn{2}{|c|}{ Alteamento } & \multicolumn{2}{c}{ Abaixamento } \\
\cline { 2 - 5 } & Perc. & Oco. & Perc. & Oco. \\
\hline /e/ & $14 \%$ & $240 / 1714$ & $\mathbf{1 6 \%}$ & $250 / 1548$ \\
\hline /o/ & $20 \%$ & $259 / 1236$ & $\mathbf{2 3 \%}$ & $212 / 904$ \\
\hline
\end{tabular}

Fonte: Celia (2004)

A flutuação entre as pronúncias médias e altas parece resultar, principalmente, da assimilação do traço de altura da vogal da sílaba seguinte, independentemente da sua tonicidade, como ilustra a Tabela 2.

Em outras palavras, em Nova Venécia, "o alteamento das vogais médias pretônicas, assim como nos demais dialetos, tem como principal fator favorecedor a presença de uma vogal alta na sílaba seguinte" (CELIA, 2004 , p. 105). Semelhantemente, a presença de uma vogal baixa na sílaba subsequente parece motivar ocorrências de abaixamento.

Aliadas a essa variável, no processo de elevação, são relevantes o travamento por consoante nasal, o tipo de atonicidade da vogal, a estrutura da sílaba em que se encontra e, ainda, as consoantes adjacentes. Por outro lado, no que tange ao abaixamento, sobressaíram apenas o fato de a vogal ser uma átona permanente ou eventual e o ponto de articulação das consoantes precedente e seguinte. 
Tabela 2 - Índices de alçamento e abaixamento de /e o/, segundo a altura da vogal tônica

\begin{tabular}{|c|c|c|c|c|c|c|c|c|}
\hline \multirow{2}{*}{$\begin{array}{c}\text { Vogal } \\
\text { pretônica }\end{array}$} & \multicolumn{4}{|c|}{ Alçamento } & \multicolumn{4}{|c|}{ Abaixamento } \\
\hline & $\begin{array}{l}\text { Vogal } \\
\text { Tônica }\end{array}$ & Perc. & Oco. & p.r. & $\begin{array}{l}\text { Vogal } \\
\text { tônica }\end{array}$ & Perc. & Oco. & p.r. \\
\hline \multirow{5}{*}{ Anterior } & [i] & $36 \%$ & $156 / 422$ & .87 & \multirow{2}{*}[i,\mathrm{u}]{} & \multirow{2}{*}{$2 \%$} & \multirow{2}{*}{$10 / 389$} & \multirow{2}{*}{.11} \\
\hline & {$[\mathrm{u}]$} & $17 \%$ & $8 / 46$ & .27 & & & & \\
\hline & \multirow{2}{*}{$\begin{array}{l}{[\mathrm{e}, \varepsilon,} \\
\mathrm{o}, \text { ○] }\end{array}$} & \multirow{2}{*}{$6 \%$} & \multirow{2}{*}{$45 / 656$} & \multirow{2}{*}{.39} & {$[e, o]$} & $6 \%$ & $33 / 524$ & .33 \\
\hline & & & & & {$[\varepsilon, 0]$} & $79 \%$ & $68 / 86$ & .98 \\
\hline & [a] & $5 \%$ & $31 / 590$ & .30 & [a] & $25 \%$ & $139 / 549$ & .81 \\
\hline \multirow{5}{*}{ Posterior } & [i] & $32 \%$ & $96 / 296$ & .71 & \multirow{2}{*}[i,\mathrm{u}]{} & \multirow{2}{*}{$7 \%$} & \multirow{2}{*}{$16 / 221$} & \multirow{2}{*}{.16} \\
\hline & {$[\mathrm{u}]$} & $18 \%$ & $7 / 37$ & .55 & & & & \\
\hline & \multirow{2}{*}{$\begin{array}{l}{[e, \varepsilon,} \\
o, \rho]\end{array}$} & \multirow{2}{*}{$19 \%$} & \multirow{2}{*}{$94 / 489$} & \multirow{2}{*}{.33} & {$[e, o]$} & $9 \%$ & $24 / 247$ & .28 \\
\hline & & & & & {$[\varepsilon, \mathrm{o}]$} & $63 \%$ & $51 / 80$ & .94 \\
\hline & [a] & $14 \%$ & $62 / 414$ & .39 & [a] & $33 \%$ & $121 / 356$ & .73 \\
\hline
\end{tabular}

Fonte: Celia (2004)

$\mathrm{Na}$ redução vocálica, os ambientes mais relevantes correspondem a itens lexicais como "maioria" (.83) e "Caetano" (.90), em que, precedendo a vogal alvo, não ocorre consoante. Além disso, casos de ausência de consoante sucedendo a vogal alvo como "campeonato" e "teoria" também parecem determinar o alçamento, atingindo, respectivamente, os índices .95 e .94. (CELIA, 2004, p. 69) e confirmando a tendência da língua à redução de hiatos.

Quanto ao abaixamento que não se deve à harmonização vocálica, parecem estar atuando, sobretudo, as características articulatórias dos segmentos adjacentes: [0] é "favorecido pelas consoantes seguintes alveolar, palatal e labiodental” (CELIA, 2004, p. 106). Salienta-se, no entanto, uma contradição: poucas das ocorrências em que uma alveolar sucede a vogal alvo correspondem a um contexto de influência exclusiva da consoante, sendo muito frequente a presença de uma vogal baixa contígua. Devido à sobreposição de fatores e à legítima influência da harmonização entre as 
vogais pretônicas e outras que integram o vocábulo em que a média se situa, no $\mathrm{PB}$, acredita-se na valorização deste aspecto em detrimento daquele.

Assim, embora na fala de Nova Venécia predomine o timbre médio fechado, os resultados relativos às variantes altas e baixas refletem a complexidade que envolve o comportamento das médias pretônicas no Brasil, sendo mais coerente caracterizá-la como uma "região de transição" (CELIA, 2004, p. 106).

\section{Falares de Minas Gerais}

Em Minas Gerais, trataram do tema Oliveira (1991, 1992, 2003, 2006), Viegas e Veado (1982), Viegas (2001), Guimarães (2007), Almeida (2008), Alves (2008), Dias (2008), Viana (2008), dentre outros.

Por se situar na fronteira entre as Regiões Norte e Sul do país, verificam-se, no Estado, distintas realidades em função, principalmente, do contato interdialetal. A fim de melhor esclarecer essa diversidade, apresentam-se resultados e considerações sobre as regiões norte, central e sul, por meio dos comentários de Almeida (2008) sobre Machacalis, e de Dias (2008) sobre Ouro Branco e Piranga.

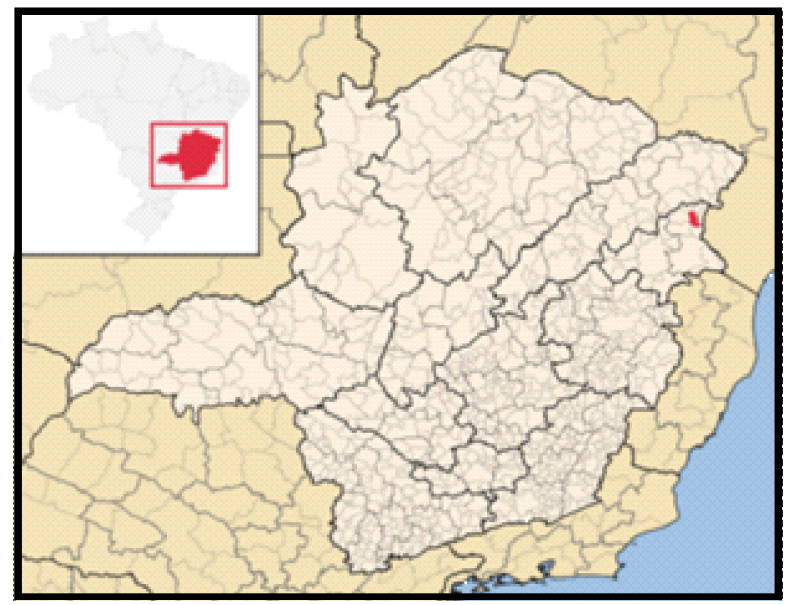

Fonte:pt.wikipedia.org

Figura 2a - Localização de Machacalis, em Minas Gerais 


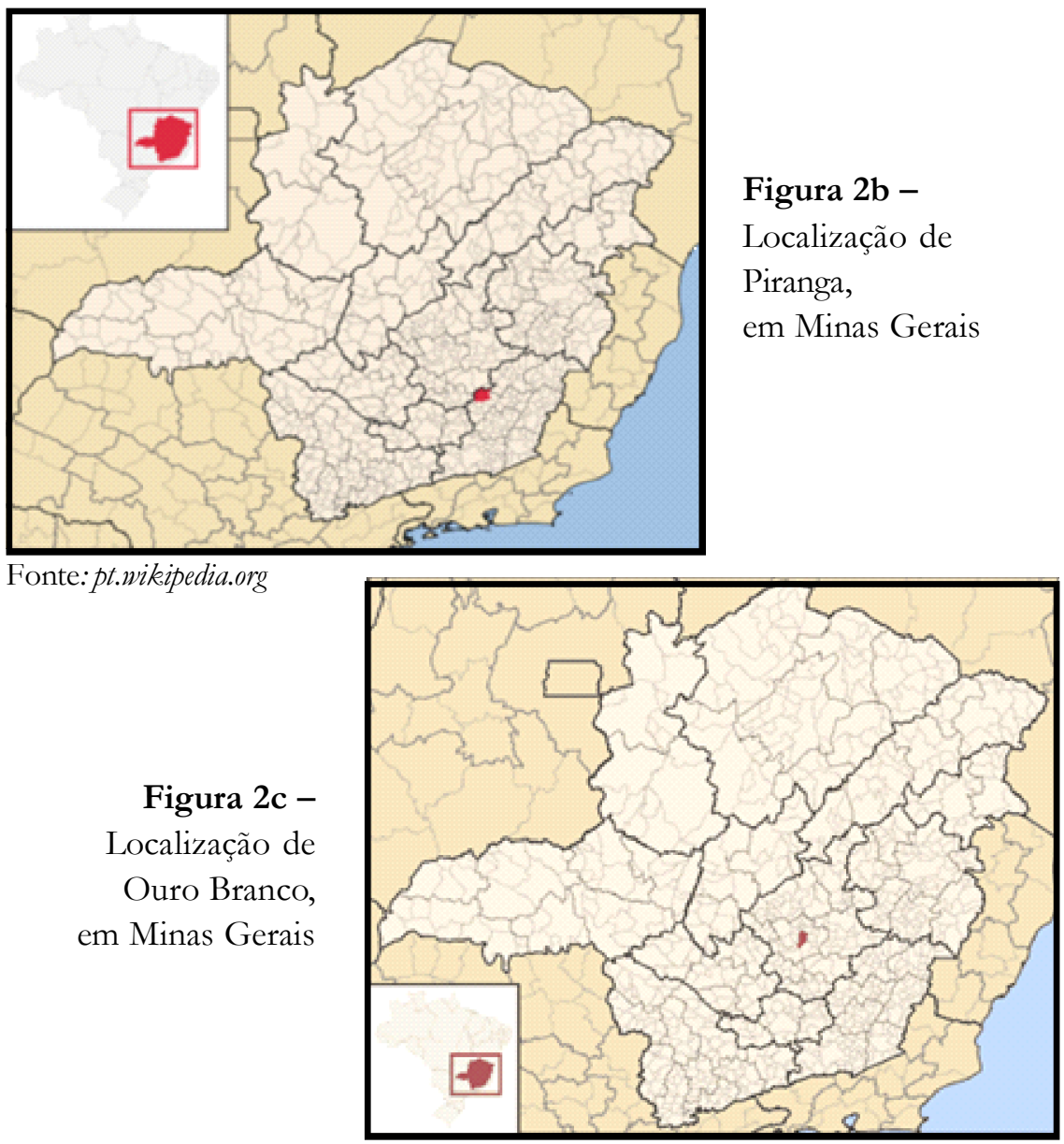

Fonte:pt.wikipedia.org

Do ponto de vista metodológico, as pesquisas de Almeida (2008) e Dias (2008) relacionam a aplicação das regras de alçamento, manutenção e abaixamento aos distintos gêneros discursivos e aos variados perfis socioeconômicos considerados nas três cidades investigadas. Os 16 informantes foram igualmente distribuídos por sexo, zona de residência e faixa etária (jovens e adultos). A primeira análise contrasta padrões linguísticos encontrados nas zonas urbana e rural de Machacalis, e a segunda contrapõe 
Piranga (Sudeste) a Ouro Branco (Centro). Além disso, os dados foram distribuídos segundo o tipo de vogal (recuada ou não recuada) e, ainda que as investigações mensurem a interferência de fatores linguísticos, desconsideram-se, por seu caráter categórico/semicategórico, os casos de vogal em início de palavra e em hiato/ditongo.

Como tais análises não se pautam por pesos relativos, esta exposição se aterá aos percentuais encontrados nas entrevistas, com base nos 6.127 dados de Almeida (2008) e 6.799 de Dias (2008).

A Tabela 3 ilustra a influência do timbre da vogal tônica, confirmando o predomínio de [o e] no dialeto mineiro. Há a possibilidade de estabelecer relações entre os dados das duas investigações, uma vez que a distinção se dá na distribuição das variantes abertas e altas em Piranga e Machacalis, onde o abaixamento é mais frequente em comparação com a elevação, e em Ouro Branco, onde o inverso se confirma.

Tabela 3 - Distribuição dos casos de manutenção, alçamento e abaixamento em entrevistas

\begin{tabular}{|c|c|c|c|c|c|}
\hline \multirow{2}{*}{\multicolumn{2}{|c|}{ Variantes }} & \multicolumn{2}{|c|}{ Almeida (2008) } & \multicolumn{2}{|c|}{ Dias (2008) } \\
\hline & & \multirow{2}{*}{$\begin{array}{c}\text { Zona Urbana } \\
935 / 1617 \\
\end{array}$} & \multirow{2}{*}{$\frac{\text { Zona Rural }}{838 / 1499}$} & \multirow{2}{*}{$\frac{\text { Piranga }}{1128}$} & \multirow{2}{*}{$\frac{\text { Ouro Branco }}{1510}$} \\
\hline 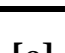 & Oco & & & & \\
\hline [e] & $\%$ & $48 \%$ & $47.7 \%$ & $51 \%$ & $78.2 \%$ \\
\hline \multirow{2}{*}{ [i] } & Oco. & $372 / 398$ & $332 / 358$ & 502 & 360 \\
\hline & $\%$ & $19.1 \%$ & $18.9 \%$ & $22.7 \%$ & $18.6 \%$ \\
\hline \multirow{2}{*}[\varepsilon]{} & Oco. & $640 / 1220$ & $587 / 1159$ & 583 & 62 \\
\hline & $\%$ & $32.9 \%$ & $33.4 \%$ & $26.3 \%$ & $3.2 \%$ \\
\hline \multirow{2}{*}{ [o] } & Oco. & $601 / 1176$ & $576 / 1085$ & 831 & 1077 \\
\hline & $\%$ & $48.2 \%$ & $49.0 \%$ & $61.6 \%$ & $82.6 \%$ \\
\hline \multirow{2}{*}{ [u] } & Oco. & $310 / 326$ & $286 / 299$ & 235 & 145 \\
\hline & $\%$ & $24.9 \%$ & $24.3 \%$ & $17.4 \%$ & $11.1 \%$ \\
\hline \multirow{2}{*}{ [0] } & Oco. & $336 / 756$ & $314 / 800$ & 281 & 82 \\
\hline & $\%$ & $26.9 \%$ & $26.7 \%$ & $21 \%$ & $6.3 \%$ \\
\hline
\end{tabular}

Fonte: Dados de Almeida (2008) e Dias (2008) 
Almeida revela que, em Machacalis, as pretônicas se distribuem, respectivamente, em médias fechadas, médias abertas e altas. Assim, no município situado na "zona do dialeto baiano" (ALMEIDA, 2008, p. 61), as ocorrências comprovam a "alternância entre a realização da vogal média baixa, vogal média alta e vogal alta” (ALMEIDA, 2008 p.28).

Em consonância com esses dados, Dias (2008) indica, para Piranga, $26.3 \%$ e $21 \%$ de abaixamento das vogais anterior e posterior, respectivamente. Em Ouro Branco, contudo, o oposto se dá: 78.2\% das ocorrências correspondem a [e] e $82.6 \%$ a [o]. Em contrapartida, $18.6 \%$ dos dados representam a vogal [i]; $11.1 \%$ o segmento [u]; e apenas $3.2 \%$ e $6.3 \%$ referem-se às vogais $[\varepsilon]$ e $[0]$.

Embora predominem, nas três localidades, as vogais médias fechadas, a manutenção de timbre em Ouro Branco se destaca, sugerindo a proximidade entre esse falar e aqueles que integram a fala fluminense.

No que tange à influência da natureza da vogal tônica na aplicação das regras de elevação e abaixamento nos três falares, a pronúncia da pretônica de ambas as séries analisadas, em Machacalis e Piranga pode "ser descrita através de um processo de harmonia vocálica” (ALMEIDA, 2008, p. 164).

Nessas duas cidades, sendo a vogal tônica baixa, maior é a probabilidade de a pretônica realizar-se como aberta (Machacalis: zona urbana - 55\% de /e/ e $42 \%$ de /o/; zona rural - 54.4\% de /e/ e 44.8\% de /o/. Piranga: /e/ - 44.8\%; /o/ - 34.5\%). Por outro lado, a presença, na palavra, de uma vogal alta acentuada parece influenciar no alçamento, de forma mais significativa no âmbito da média anterior do que no da posterior, já que os percentuais de [i] (Machacalis: zona urbana $-45.2 \%$; zona rural $-50.2 \%$. Piranga: 42.9\%) são maiores que os de [u] (Machacalis: zona urbana - 43.5\%; zona rural - 42.9\%. Piranga: $29.3 \%$ ).

Em Ouro Branco, também se ressalta a harmonia entre vogais, apesar de menos frequente: os índices de alçamento são maiores precedendo uma vogal alta tônica, tanto na série anterior (34.9\%) quanto na posterior $(18.6 \%)$. De igual modo, pretônicas médias abertas são mais frequentes em presença de vogal aberta tônica (/e/: 8.5\%; /o/: 11.9\%).

Ponderados esses aspectos, restam, por fim, algumas considerações sobre a atuação do fenômeno de redução vocálica que, nos falares em questão, parece ser condicionado principalmente pelo ponto e modo de articulação dos segmentos adjacentes à pretônica. 
Para Machacalis, o modo de articulação do segmento antecedente se destaca nas realizações abertas de ambas as séries. Sucedendo consoantes líquidas e nasais, a variante $[\varepsilon]$ é mais recorrente, enquanto a pronúncia [0] sobressai quando a consoante precedente é um tepe ou uma velar, fricativa ou africada. No que tange à passagem de uma vogal média a alta por influência do contexto precedente, segmentos nasais viabilizam o alçamento de /e/ e as líquidas a elevação de /o/.

Em Piranga e Ouro Branco, o tepe é o fator mais saliente para o alçamento da média anterior, sendo sucedido pelas consoantes nasais. $\mathrm{Na}$ série posterior, o alçamento se mostra pouco atuante no estudo de Dias (2008), sendo os percentuais mais elevados em ataques preenchidos por africadas e fricativas, em Piranga (22.7\%), e oclusivas, em Ouro Branco $(13.2 \%)$.

Quanto às variantes baixas, percebe-se que, nas duas séries, consoantes nasais e líquidas se mostram mais relevantes no falar de Piranga, embora o processo de abaixamento de /o/ seja mais frequente. Assim, para a vogal /e/ tem-se $46.2 \%$ de ocorrências da variante baixa depois de consoantes nasais e $29.1 \%$ depois de segmentos líquidos. Por outro lado, no caso de [0], $57 \%$ das ocorrências correspondem ao contexto precedente nasal, ao passo que $62.5 \%$ se devem ao ataque preenchido por consoantes líquidas.

Nas duas investigações, o ponto de articulação da consoante precedente indica um maior favorecimento da aplicação da regra de abaixamento, em detrimento das realizações altas. Como é possível depreender do Gráfico 1, adiante, em Machacalis, consoantes dorsais se mostram mais determinantes para o abaixamento, embora os maiores índices de alçamento também remetam a esses segmentos. De maneira semelhante, em Piranga, 41.3\% dos casos de vogal baixa $[\varepsilon]$ e $29.7 \%$ das ocorrências de [i] se apresentam sucedendo segmentos dorsais/palatalizados. Embora, em Ouro Branco, os percentuais de ambos os processos sejam bem mais reduzidos, 25.6\% dos dados representam a vogal alçada e $5.6 \%$, a vogal [ع]. 


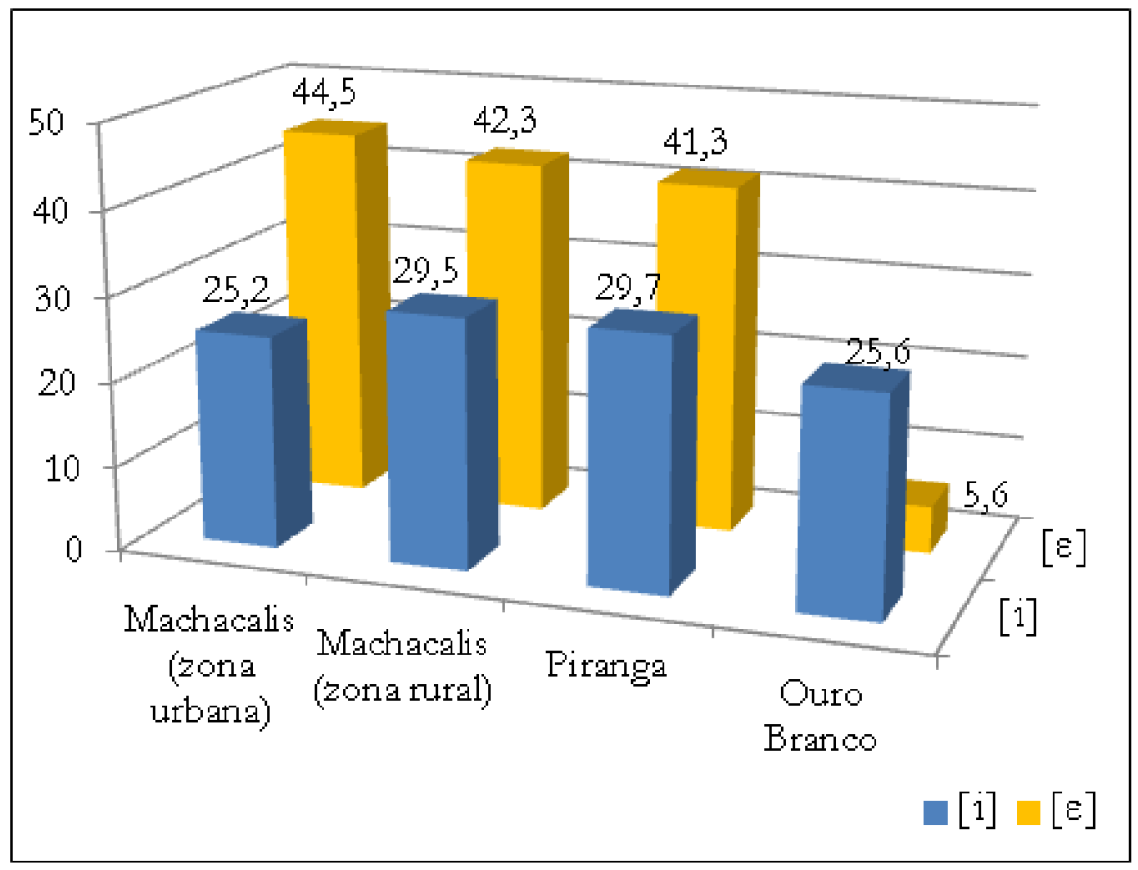

Fonte: Dados de Almeida (2008) e Dias (2008).

Gráfico 1 - Percentuais de ocorrência das variantes [i] e [ $[\varepsilon$ ], precedidas por consoantes dorsais/palatalizadas

Em Machacalis, os índices mais elevados de média baixa posterior se encontram em presença de consoantes coronais/tepe (zona urbana: 51.7\%; zona rural: $47.9 \%$ ). Por outro lado, as realizações altas diferem quanto à zona de residência do falante: na área urbana, a maior frequência corresponde a consoantes labiais (31.2\%), enquanto na zona rural são os segmentos dorsais/ palatalizados os que mais motivam a presença da variante $[\mathrm{u}](27.7 \%)$.

Em Piranga e Ouro Branco, consoantes labiais se destacam no processo de elevação, com 30.8\% e $16.4 \%$ de ocorrências, respectivamente. Para o abaixamento, em Ouro Branco, é o mesmo ambiente que se mostra mais atuante $(8.4 \%)$, ao passo que, em Piranga, consoantes coronais prevalecem $(30.1 \%)$ precedendo a média aberta. 
Restam, enfim, alguns esclarecimentos sobre as consoantes subsequentes. À semelhança das ocorrências supracitadas, percebe-se uma motivação maior sobre os casos de abaixamento em detrimento da elevação em Machacalis e Piranga. Como ilustra o Gráfico 2, consoantes nasais e líquidas favorecem, respectivamente, as variantes [i] e [ $\varepsilon$ ], nas duas áreas. Em Ouro Branco, embora a pronúncia mais incidente seja [e], os percentuais de alçamento e abaixamento mais elevados correspondem a contextos em que o segmento é sucedido por esses segmentos.

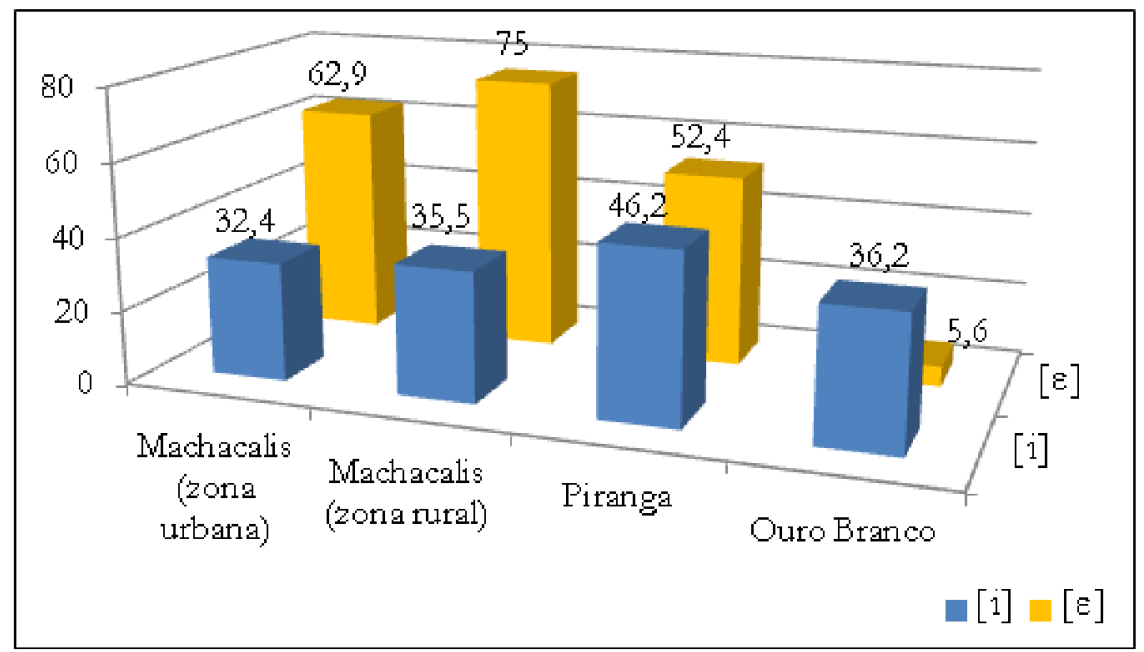

Fonte: Dados de Almeida (2008) e Dias (2008).

Gráfico 2 - Percentuais de ocorrência das variantes [i] e [ $\varepsilon$ ], sucedidas por consoantes nasais/líquidas

No que tange ao ponto de articulação, consoantes dorsais/palatalizadas subsequentes à pretônica se destacam em ambos os processos e falares, apresentando, em Machacalis, respectivamente, $22.8 \%$ e 44.2\% de ocorrências altas e baixas na zona urbana; e $22 \%$ e $44 \%$ de dados de [i] e de [ $\varepsilon$ ] na zona rural. De maneira semelhante, em Piranga 41.3\% dos dados de vogal aberta e $29.7 \%$ dos casos de elevação são sucedidos pelas mesmas consoantes. Por fim, em Ouro Branco, 25.6\% dos casos de [i] e 5.6\% dos de [ع] devem-se à presença das mesmas consoantes sucedendo a vogal alvo: 


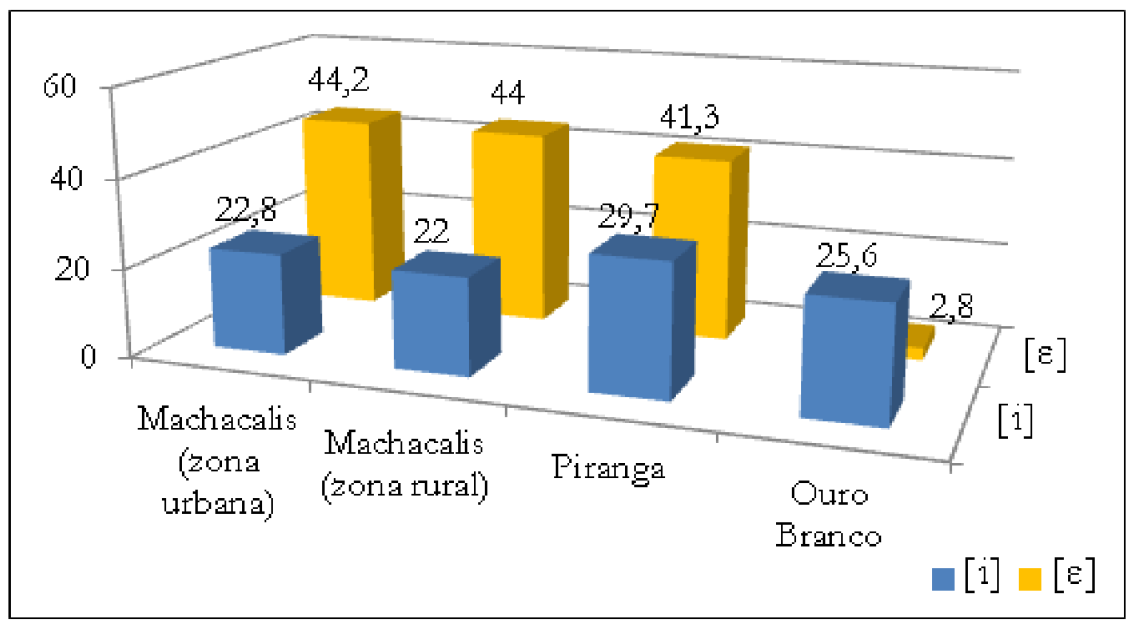

Fonte: Dados de Almeida (2008) e Dias (2008).

Gráfico 3 - Percentuais de ocorrência das variantes [i] e [ $\varepsilon$ ], sucedidas por consoantes dorsais/palatalizadas

Quanto à vogal posterior, em Machacalis, as consoantes líquidas são as responsáveis pelos percentuais mais elevados de alçamento (zona urbana: 41.7\%; zona rural: 40.4\%), enquanto o tepe (zona urbana: $57.9 \%$; zona rural: $57.4 \%$ ) e as consoantes velares, africadas e fricativas (zona urbana: $51.2 \%$; zona rural: $50.2 \%$ ) foram mais influentes para $[\varepsilon]$. Em Piranga, consoantes líquidas se destacam tanto para o alçamento (33.6\%) quanto para o abaixamento (43.6\%) de /o/. Em Ouro Branco, os maiores percentuais para esses processos se encontram na presença de fricativas/africadas (19.3\%) e do tepe $(33.3 \%)$, respectivamente.

Além disso, o estudo de Almeida (2008) sugere que segmentos labiais (zona urbana: $27.8 \%$; zona rural: $27.8 \% \%$ ) e tepe/coronais (zona urbana: 27.7\%; zona rural: $24.4 \%$ ) sejam determinantes no alçamento de /o/. Para o abaixamento, sobressaem elementos dorsais/palatalizados (zona urbana: 49.2 \%; zona rural: 45.1\%). Em Dias (2008), contudo, parece não haver distinção quanto à influência do ponto de articulação da consoante seguinte: entre os dois processos focalizados nas duas cidades, são as consoantes dorsais/ palatalizadas os segmentos que apresentam percentuais mais elevados (Piranga: 
abaixamento - 29.7\% e alçamento - 24\%; Ouro Branco: abaixamento $10.9 \%$ e alçamento $-17.9 \%$ ).

Cabe salientar que, para as realizações altas e baixas, em ambas as séries e áreas de residência, a observação dos itens lexicais comprova a presença de uma vogal baixa ou alta, acentuada ou não, sucedendo a pretônica e de palavras iniciadas pela forma "de/des-" (prefixal ou não). Dessa maneira, por sua reconhecida relevância no $\mathrm{PB}$, esses contextos permitem que se valorize a harmonização vocálica, em detrimento da redução, tanto no alçamento quanto no abaixamento das pretônicas em Minas Gerais.

Em suma, em conformidade com a perspectiva de Guimarães (2007), esses estudos procuram demonstrar que Minas Gerais “pertence à área de falar Baiano, à área de falar Sulista, à área de falar Fluminense e à área de falar Mineiro", sendo marcado por "várias maneiras de se falar o português" (VIEGAS apud GUIMARÃES, 2007, p. 16). Assim, no que toca à variação pretônica, enquanto os dados dos municípios de Machacalis e Ouro Branco parecem apresentar características que poderiam inseri-los nas áreas dialetais Norte e Sul, respectivamente, Piranga é considerado um falar de transição, aproximando-se da realidade linguística de Nova Venécia.

\section{Um Falar de São Paulo}

No Estado de São Paulo, consideram-se os estudos de Silveira (2008) e de Carmo (2009) sobre a norma de prestígio do município de São José do Rio Preto, noroeste paulista. Tais investigações pautam-se no corpus IBORUNA e conjugam aspectos extra e intralinguísticos, analisando o alçamento em itens de naturezas distintas.

A primeira investigação concentra-se na aplicação da regra de alçamento em nomes, enquanto a segunda se atém aos verbos. As ocorrências desta se dividem em 2.455 casos de vogal média anterior e 2.147 de vogal posterior; já naquela encontram-se 2.246 dados de /e/ e 1.590, de /o/. No que tange à aplicação da regra de elevação, contudo, percebe-se certa proximidade em favor da manutenção de timbre, como expõe a Tabela 4. 


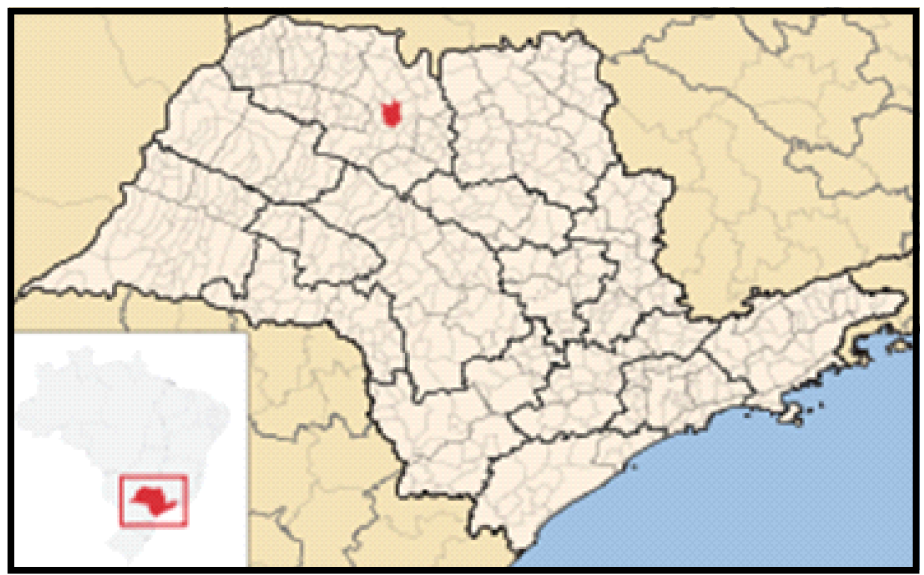

Fonte: pt.wikipedia.org

Figura 3 - Localização da cidade de São José do Rio Preto, em São Paulo

Tabela 4 - Índices de alçamento na fala feminina culta de São José do Rio Preto

\begin{tabular}{c|c|c|c|c}
\hline & \multicolumn{2}{|c|}{$/ \mathrm{e}$} & \multicolumn{2}{c}{$/ \mathrm{o} /$} \\
\cline { 2 - 5 } & Perc. & Oco. & Perc. & Oco. \\
\hline Silveira (2008) & $\mathbf{1 3 \%}$ & $297 / 2246$ & $\mathbf{1 4 \%}$ & $227 / 1590$ \\
\hline Carmo (2009) & $\mathbf{1 6 \%}$ & $390 / 2455$ & $\mathbf{1 0 \%}$ & $219 / 2147$ \\
\hline
\end{tabular}

Fonte: Dados de Silveira (2008) e Carmo (2009).

A escassez de dados de vogais altas permite afirmar que "no dialeto do noroeste paulista, as vogais médias [e o] predominam sobre as altas [i u], não havendo tendência ao alçamento." (SILVEIRA, 2008, p. 83). Apesar disso, em casos categóricos/semicategóricos, como "m[i]nino", "s[i]nhora" e "b[u]nito", "a manutenção das médias [e o] acontece somente do ponto de vista ortográfico" (SILVEIRA, 2008, p. 83).

Interpretando os processos de harmonização e redução vocálicas como convergentes, traçaram-se variáveis linguísticas que remetem à assimilação entre as vogais e às características articulatórias das consoantes 
que cercam a pretônica. Controlaram-se, por exemplo, a presença de uma vogal alta na palavra, a relação desta com o acento e a influência deste no alçamento, o ponto de articulação das consoantes adjacentes à vogal alvo e o tipo de sílaba em que ela incide. Apesar de se reconhecer certa proximidade entre as variantes das variáveis que integram as investigações, estas apresentam peculiaridades: o estudo dos nomes considera a nasalidade da sílaba e o grau de atonicidade da pretônica, enquanto o dos verbos mensura, também, o modo de articulação dos segmentos adjacentes, a conjugação dos itens estudados e o tipo de sufixo que contenha a vogal.

As duas investigações baseiam-se na fala de dezesseis informantes do sexo feminino com nível superior de escolaridade e residentes no município de São José do Rio Preto, cuja única diferença social é a faixa etária, já que as informantes se distribuem, igualmente, por quatro distintas gerações (16-25 anos; de 26-35 anos; de 36-55 anos; e mais de 56 anos).

Dentre outras variáveis selecionadas, destacam-se a influência da presença de uma vogal alta tônica na palavra e das características articulatórias das consoantes, independentemente da natureza da vogal alvo e da classe estudada. No que se refere à existência de uma vogal alta tônica na palavra e sua interferência na aplicação da regra variável de alçamento em nomes, Silveira (2008, p. 86) afirma que

... é a vogal tônica anterior /i/ o ambiente mais favorável à regra, tanto no contexto de pretônica /e/ (PR .98), quanto no de pretônica /o/ (PR .91), [...]. A vogal tônica posterior /u/, de modo diferente, tende a motivar muito mais o alçamento de /o/ (PR .85), do que de /e/ (PR .50).

Defendendo que o cruzamento entre a tonicidade e a altura da vogal da sílaba subsequente permite avaliar "se a presença de uma vogal alta átona na sílaba seguinte à da pretônica-alvo, [...], apresenta ou não a mesma influência que a presença de uma vogal alta tônica nesse mesmo contexto", Carmo (2009, p. 63, grifos da autora) se utiliza de estratégias distintas, mas apresenta resultados semelhantes.

A comparação entre os dados de alçamento por aparente influência de uma vogal alta anterior tônica ou átona revela que o processo é mais 
saliente no primeiro grupo, em /e/ e /o/. Entretanto, diante de uma legítima variação em função da tonicidade, não se pode estabelecer este elemento como determinante para a incidência de vogais elevadas, pois se verificam casos "(i) de não alçamento nesse contexto, [...]; e (ii) de alçamento quando há vogal alta átona na sílaba seguinte” (CARMO, 2009, p. 70). A Tabela 5 ilustra o diálogo entre esses fatores nas investigações focalizadas, destacando apenas os pesos relativos encontrados em Silveira (2008), já que, em Carmo (2009), os percentuais descritos resultam do mencionado cruzamento.

Tabela 5 - Índices de alçamento de /e/ e de /o/ por influência da tonicidade da vogal anterior assimiladora

\begin{tabular}{c|c|c|c|c|c|c}
\hline \multirow{2}{*}{ Tipo de Vogal } & \multicolumn{3}{|c|}{ Silveira (2008) } & \multicolumn{2}{c}{ Carmo (2009) } \\
\cline { 2 - 6 } & \multicolumn{2}{|c|}{$/ \mathrm{e}$} & \multicolumn{2}{c|}{$/ \mathbf{o} /$} & $/ \mathrm{e} /$ & $/ \mathbf{o} /$ \\
\hline [i] tônica & $\mathbf{3 9 \%}$ & $\mathbf{. 9 8}$ & $\mathbf{4 1} \%$ & $\mathbf{. 9 1}$ & $\mathbf{6 2} \%$ & $\mathbf{6 0 \%}$ \\
\hline [i] átona & $8 \%$ & .83 & $13 \%$ & $\mathbf{. 9 2}$ & $28 \%$ & $16 \%$ \\
\hline [u] tônica & $8 \%$ & .50 & $28 \%$ & $\mathbf{. 8 5}$ & $0 \%$ & $\mathbf{3 1 \%}$ \\
\hline [u] átona & $4 \%$ & .78 & $6 \%$ & .62 & $16 \%$ & $12 \%$ \\
\hline
\end{tabular}

Fonte: Dados de Silveira (2008) e Carmo (2009).

Os dados de vogal posterior fechada tônica ou átona se mostraram notavelmente mais reduzidos. Não impedem, porém, que se confirme a relevância de atrelar o tipo e a altura da vogal assimiladora ao acento. A vogal [i] tônica parece determinar o alçamento tanto da anterior quanto da posterior, sendo relevante também, quando átona, no que concerne a /o/, embora, neste caso, a homorgânica [u] acentuada se apresente como o segundo fator mais significativo.

Outras duas variáveis remetem, ainda, ao processo de harmonia vocálica na proposta de Carmo (2009): a conjugação do verbo e o tipo de sufixo presente nos vocábulos observados. No entanto, enquanto a importância da primeira variável se restringe à série anterior, a segunda abrange ambas as séries no dialeto rio-pretano. Compatíveis com os casos de influência de uma vogal alta anterior homorgânica na palavra, os dados da terceira conjugação se mostraram mais sujeitos ao alçamento de /e/ (PR .89) com $76 \%$ de elevação, contra 8\% e 15\%, nas primeira e segunda conjugações, respectivamente. 
No que tange ao tipo de sufixo que a pretônica integra, apenas exploraram-se aqueles cuja estrutura abarca uma vogal alta. Esses dados se distribuem em 373 e 177 ocorrências para as vogais anterior e posterior, respectivamente, e integram as desinências número-pessoais $-\mathrm{i}$ e as modo-temporais do pretérito imperfeito (-ia) e do futuro do pretérito (-ria). Os pesos relativos comprovam uma maior relevância dos sufixos de pretérito imperfeito -ia, tanto para /e/ (PR .69) quanto para /o/ (PR .51). A desinência número pessoal -i mostrou-se neutra para a média recuada (.50) e favorecedora da mudança para a não recuada (.59). Por fim, ao sufixo modo-temporal de futuro do pretérito foram atribuídos os pesos .08 e .00 para as vogais anterior e posterior, respectivamente. Em consonância com Collischonn e Schwindt (2004), Carmo (2009, p.75) justifica esses últimos índices alegando:

... há um sufixo verbal que, ao contrário dos demais, é forte desfavorecedor da aplicação do processo. [...] A princípio, esse resultado causa estranheza, pois há uma vogal alta nesse sufixo e, além disso, em uma sílaba tônica, contexto que [...] favorece altamente a aplicação do alçamento.

Acrescenta-se a essas considerações a baixa frequência de uso, em português e na amostra (78 dados em 373 de /e/ e 23 em 177 de /o/), de tal forma que costuma ser substituída pelo pretérito imperfeito ou por estratégias de modalização. Além disso, tais estruturas funcionam como palavras prosódicas distintas, o que inibiria o alçamento, pois a harmonização vocálica não atravessa essas fronteiras (CARMO, 2009, p.75).

Quanto à redução vocálica, em ambos os estudos, o ponto de articulação das consoantes adjacentes se destaca. Enquanto a primeira abordagem se concentra em consoantes labiais, alveolares, palatais e velares, a segunda focaliza os pontos labial, coronal e dorsal. Por fim, na proposta sobre verbos, a ordem de seleção parece revelar, ainda, que, apesar de também atuar na série anterior, nas vogais posteriores, o processo de redução vocálica se mostrou mais determinante.

Sobre a atuação das variáveis ponto de articulação da consoante precedente e subsequente, Silveira (2009, p. 123) destaca que, nos dois contextos, há uma "relação entre consoante labial e alçamento da pretônica 
/o/, e [...] entre consoante velar e alçamento da pretônica /e/." Acrescenta, todavia, que a variante $[\mathrm{u}]$ parece ser mais frequente se sucedida por segmentos palatais.

A proposta de Carmo (2009) sugere índices (.80 para /e/ e .65 para /o/) que demonstram que, independentemente da natureza da vogal alvo, a elevação é favorecida pela presença de uma consoante dorsal precedente. Acredita-se que essa característica se intensifique na série posterior, em virtude da presença do traço dorsal em vogais dessa natureza.

A observação do fenômeno do alçamento de /e/ e de /o/ em virtude do ponto de articulação da consoante seguinte na mesma amostra se aproxima do supramencionado. Consoantes dorsais sucedendo a vogal alvo parecem influenciar mais a elevação de /e/ (.57), enquanto as coronais favoreceriam o alteamento, independentemente da natureza da vogal alvo (.52 para /e/ e .57 para /o/). A influência do traço [+ coronal] se justifica plenamente na série anterior, uma vez que os segmentos vocálicos médio e alto desse grupo possuem tal traço. Em contrapartida, na série posterior, o oposto se dá, apesar de os índices demonstrarem certo favorecimento do traço em questão.

Para todos esses casos, Carmo (2009) enfatiza, porém, a possibilidade de sobreposição de fatores, já que a presença de uma vogal alta contígua é recorrente, caracterizando um ambiente favorável ao alçamento por harmonização vocálica. Estabelece, ainda, para uma análise coerente dos dados de aparente redução vocálica de /e/, um cruzamento entre o ponto e modo de articulação dos elementos adjacentes às vogais médias, o que confirma a supremacia dos pontos em detrimento dos modos.

Para os dados de /o/, são as consoantes nasais precedentes e seguintes os elementos que mais parecem determinar o alçamento (.67 para cada contexto). Por essa razão, o cruzamento realizado é entre o ponto de articulação e tipo de sílaba em que a vogal se apresenta:

... quando a consoante nasal segue imediatamente a pretônica, o alçamento é favorecido pela nasalidade $[. .$.$] fonética [. .$.

Esse resultado também foi encontrado por Viegas (1987), que o explica afirmando que, enquanto a vogal presente em sílaba travada por consoante nasal não antecipa a articulação da consoante que a segue, a vogal seguida por elemento nasal na sílaba seguinte antecipa, e, ao fazer isso, a língua se eleva, o que favorece a emissão de uma vogal alta. (CARMO, 2009, p. 93-94). 
Assim, em São José do Rio Preto,

... o alçamento vocálico caracteriza-se como um fenômeno fonológico de baixa produtividade [...] mas não menos importante para a caracterização da Língua Portuguesa, na medida em que fornece subsídios para comparações interdialetais e, consequentemente, para a descrição das vogais átonas do PB. (SILVEIRA, 2009, p. 85).

\section{Falares do Rio de Janeiro}

No Estado do Rio de Janeiro, destacam-se, nessa ordem, as abordagens de: Yacovenco (1993) ${ }^{1}$, sobre a fala culta carioca, e de Rocha (2013), sobre inquéritos realizados no município de Nova Iguaçu, na Região Metropolitana do Rio de Janeiro.

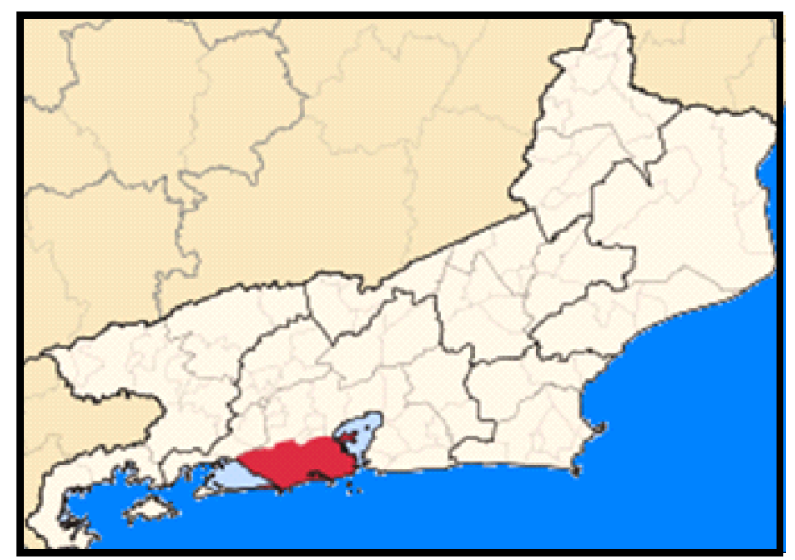

Fonte: pt.wikipedia.org

Figura 4 - Localização da cidade do Rio de Janeiro

${ }^{1}$ Callou, Leite e Coutinho (1991), como se poderá verificar na bibliografia, realizaram os primeiros estudos sobre as médias pretônicas na fala carioca. Optou-se, no entanto, por comentar apenas o estudo de Yacovenco não só por sua maior abrangência, mas, também, por se basear em alguns dos inquéritos levados em conta pelos referidos pesquisadores. 
Baseando sua análise em entrevistas que integram o corpus NURC/RJ da década de 1970, Yacovenco analisa dezoito informantes que se distribuem igualmente por sexo, três faixas etárias e três distintas zonas de residência, investigando o contraste entre manutenção, abaixamento e alteamento. Apesar de fornecer uma perspectiva mais abrangente do comportamento das médias pretônicas, prioriza a determinação dos fatores influentes para a retenção do timbre fechado, partindo do pressuposto de que a regra de manutenção é "a norma-padrão da comunidade culta carioca", podendo ser relacionada "a uma tentativa de restauração do sistema lingüístico, [...] que estaria ligada a uma tentativa de os falantes cultos aproximarem sua pronúncia da grafia oficial" (YACOVENCO, 1993, p. 172).

Corroborando essa afirmação, o confronto entre as práticas orais de homens e mulheres, residentes nas zonas norte, sul e suburbana, distribuídos igualmente entre jovens, indivíduos de meia idade e idosos, revela que

... os jovens, os informantes do sexo feminino e os residentes na zona norte são os que mais favorecem a regra de manutenção, quando contraposta à de alteamento. Por outro lado, os informantes do sexo masculino e os moradores da zona sul são os que mais inibem essa regra. (YACOVENCO, 1993, p. 173).

No âmbito estrutural, controlaram-se a distância entre a vogal em foco e outra alta presente na palavra, o timbre das vogais tônica e da átona subsequente, a natureza da atonicidade da sílaba em que a pretônica se situa e o ponto de articulação das consoantes que lhe são adjacentes.

Como ilustra a Tabela 6 , com variantes da variável dependente, a autora estabelece sete possibilidades. Estas se restringem, posteriormente, a cinco, devido às semelhanças fonéticas entre os diferentes tipos de ditongos postulados e à escassez de dados que a eles se referem na amostra. 
Tabela 6 - Distribuição de vogais pretônicas de acordo com as diferentes variantes de uma mesma variável dependente

\begin{tabular}{c|c|c}
\hline TIPO DE VOGAL & Oco. & Perc. \\
\hline Anterior oral & 2070 & 49.4 \\
\hline Posterior oral & 1188 & 28.4 \\
\hline Anterior nasal & 535 & 12.8 \\
\hline Posterior nasal & 264 & 6.3 \\
\hline Ditongo pleno & $\mathbf{9 1}$ & $\mathbf{2 . 2}$ \\
\hline Ditongo reduzido & $\mathbf{3 7}$ & $\mathbf{0 . 9}$ \\
\hline Ditongo reduzido e alteado & $\mathbf{4}$ & $\mathbf{0 . 1}$ \\
\hline
\end{tabular}

Fonte: Yacovenco (1993).

Entre as 4.189 ocorrências, predominam vogais orais, sendo as anteriores mais frequentes do que as posteriores. Em virtude dos propósitos comparativos deste capítulo, focalizam-se apenas esses dados, que correspondem a $78 \%$ da amostra total, isto é, a 3.258 casos. Além disso, priorizam-se os processos de manutenção e alçamento, embora a investigação não se limite a essas pronúncias.

Entre as vogais orais, verificam-se índices superiores de manutenção do timbre médio (63.8\%), em detrimento das realizações das vogais [i u] $(32.9 \%)$. Embora em níveis muito reduzidos $(3.3 \%)$, dados de $[\varepsilon$, o] também foram registrados e, à semelhança dos casos de elevação, atribuídos principalmente à atuação da harmonia vocálica.

No que tange à observação das pronúncias altas, a primeira estratégia empregada na elaboração de potenciais ambientes favorecedores é a eliminação de casos (semi)categóricos como aqueles em que a vogal anterior inicial é travada por /S/ (89.2\%), em que integra a forma des-, prefixal ou não, $(87.5 \%)$ e, ainda, em que é precedida por consoante africada $(100 \%)$. Abstraídos esses dados, destaca-se o tipo de vogal tônica da palavra, variável que, segundo Yacovenco (1993, p. 96), "é importante para a atualização das regras variáveis, posto que está relacionado à regra de harmonização vocálica, isto é, à influência da vogal tônica sobre a pretônica."

O comportamento das vogais anterior e posterior contrasta quanto ao alçamento, uma vez que, em favor da aplicação dessa regra, em relação a 
/e/, atuam tanto a alta homorgânica (.74) quanto a não homorgânica (.72), enquanto, em referência a /o/ decorre, principalmente, da presença da tônica não homorgânica [i] (.71).

Por outro lado, a retenção da vogal média anterior parece decorrer de segmentos de mesmo timbre (.59) e baixos (.54). Na série recuada, também se destacam as vogais baixa (.66), alta homorgânica (.57) e médias (.51).

Complementando sua descrição, Yacovenco (1993) salienta que os casos de alçamento e manutenção podem variar em decorrência das características articulatórias das consoantes precedente e seguinte à vogal alvo e da natureza da atonicidade da sílaba em que esta se insere.

$\mathrm{Na}$ série anterior, o contexto de ataque vazio contribui significativamente para a elevação (.78). Além desse ambiente, o preenchimento da posição pré-vocálica por segmentos velares (.77), por grupos consonantais (.57) e, ainda, por alveolares (.52) e labiais (.51) contribui para a aplicação da regra no dialeto. Para a pronúncia [u] são, respectivamente, mais determinantes contextos em que, precedendo a vogal pretônica, se encontram segmentos velares (.69), labiais (.65) e alveolares (.51).

Para a manutenção de timbre médio-fechado, os segmentos que mais se destacam para a variante [e] são: consoantes palatais (.76), vibrantes (.72) e vogais (.67). Para [o], são, também, altamente relevantes, vogais (.94), consoantes palatais (.93), vibrantes (.77), grupos consonantais (.70), além ataque vazio (.63).

Sobre a influência dos elementos que sucedem a vogal alvo e a frequência dos processos de alçamento e manutenção, Yacovenco (1993, p. 109) comprova que

As consoantes vibrantes $(85.2 \%)$ e as palatais (84.5\%), [...] são as que mais contribuem para a regra de manutenção da anterior oral que as antecede.

Já as consoantes velares são as que mais atuam sobre a anterior oral para sua realização alta, atingindo o índice de 38.5\%. Nota-se que essas consoantes agiam de modo relevante para a realização da regra de alteamento quando se encontravam antes da pretônica.

Além disso, 
... os segmentos que mais atuam sobre a posterior oral para a realização da regra de manutenção são os grupos consonânticos, as consoantes alveolares e as velares - 74.6\%,74.1\% e 71.4\%, respectivamente. Verifica-se que as velares, quando em posição precedente à posterior pretônica, eram as que mais favoreciam a regra de alteamento. Influenciando a atualização alta da posterior oral, encontram-se, em ordem de importância, os segmentos vocálicos, as consoantes labiais e as palatais $(54.6 \%, 38.3 \%$ e $33.3 \%$, respectivamente). Confrontando-se esses resultados com os ocorridos com os segmentos em posição precedente, verifica-se que as labiais atuam sobre a regra de alteamento em ambas as posições, porém as palatais e os segmentos vocálicos, quando em posição precedente, são propensos a favorecer a regra de manutenção. (YACOVENCO, 1993, p. 110).

Em consonância com tais aspectos, surge, enfim, o grau de atonicidade da vogal alvo, em que, para estabelecer diferentes níveis de influência, se propõem, inicialmente, quatro fatores. Por seu caráter categórico/ semicategórico de manutenção em ambas as séries, contudo, as vogais de atonicidade baixa foram desconsideradas e as ocorrências redistribuídas em três níveis, comprovando que vogais átonas permanentes beneficiam o alteamento tanto de /e/ (.63) quanto de /o/ (.51), embora entre as vogais posteriores sobressaiam as átonas eventuais (.55).

No que tange à retenção de timbre, os graus que mais se destacam para /e/ são a atonicidade casual média (.63), e a relação entre o timbre da vogal alvo e aquele presente na palavra base (.59). Para /o/, embora todos os pesos relativos sejam inferiores a .50 , mostrando certo desfavorecimento à aplicação da regra de manutenção, o índice mais elevado remete ao contexto de atonicidade permanente (.49). Assim, os dados de Yacovenco comprovaram "que as vogais médias pretônicas apresentavam três realizações, cada uma delas obedecendo a uma das regras variáveis, que são a de abaixamento, a de alteamento e a de manutenção. Constatou-se que esta última era a mais freqüente" (YACOVENCO, 1993, p. 172) e que

... se refere a um estágio de estabilização da língua, não estando, conseqüentemente, em um processo de evolução ou regressão, posto 
que os jovens são os que mais usam esta regra, ao passo que o grupo dos intermediários e o dos idosos apresentam índices próximos, porém mais baixos que o dos jovens. (YACOVENCO, 1993, p. 173).

Por fim, em um estudo mais recente, Rocha (2013) investiga o comportamento das vogais médias pretônicas na fala de Nova Iguaçu, município da Região Metropolitana do Rio de Janeiro, focalizando as ocorrências de alçamento e manutenção de timbre médio fechado de /e/ e /o/, isoladamente. Ainda que se trate de duas análises principais (variacionista e lexical), nesta seção serão descritos apenas os resultados mais relevantes da abordagem sociolinguística.

A análise variacionista considerou 19.079 ocorrências, sendo 11.378 referentes a /e/ e 7.701 a /o/. Conforme ilustra a Tabela 7 , uma vez descartados os casos (semi)categóricos e os dados escassos de ditongação e abertura, os inputs de aplicação de [i] e [u] são baixíssimos, confirmando a manutenção como norma no dialeto investigado.

Tabela 7 - Distribuição dos casos de manutenção e alçamento de /e o/

\begin{tabular}{c|c|c|c}
\hline Pretônica/Peso relativo & & Oco. & \% \\
\hline Anterior & {$[\mathrm{i}]$} & 946 & $15.2 \%$ \\
\cline { 2 - 4 } Alçamento: input.06 & {$[\mathrm{e}]$} & 5.267 & $84.8 \%$ \\
\hline Posterior & {$[\mathrm{u}]$} & 874 & 20.6 \\
\cline { 2 - 4 } Alçamento: input .09 & {$[\mathrm{o}]$} & 3.374 & 79.4 \\
\hline
\end{tabular}

Fonte: Rocha (2013).

Em meio às especificidades encontradas em cada série, constatou-se que as variantes [e o] são mais prováveis se, sucedendo a vogal alvo, se apresentam segmentos [-altos]. Por outro lado, a contiguidade com a vogal [i], sobretudo tônica, se destaca nas duas amostras como ambiente em que as variantes [i] (.95) e [u] (.91) são mais recorrentes, confirmando a importância do processo de harmonização vocálica, independentemente da variante em destaque. 
Tabela 8 - Índices de alçamento de / e o/ segundo o tipo de vogal contígua em Nova Iguaçu

\begin{tabular}{|c|c|c|c|c|c|c|c|c|c|}
\hline \multirow{2}{*}{\multicolumn{2}{|c|}{$\begin{array}{c}\text { Variável Tipo de vogal } \\
\text { contígua }\end{array}$}} & \multicolumn{2}{|c|}{ [i] } & \multirow{3}{*}{$\begin{array}{l}\text { PR } \\
.95\end{array}$} & \multirow{3}{*}{\begin{tabular}{|c|} 
Total \\
882
\end{tabular}} & \multicolumn{2}{|c|}{$[\mathrm{u}]$} & \multirow{3}{*}{$\begin{array}{l}\text { PR } \\
.57\end{array}$} & \multirow{3}{*}{$\begin{array}{r}\text { Total } \\
133\end{array}$} \\
\hline & & \multirow{2}{*}{$\begin{array}{c}\% \\
52.2\end{array}$} & \multirow{2}{*}{$\begin{array}{c}\text { Oco. } \\
460\end{array}$} & & & $\%$ & Oco. & & \\
\hline \multirow{3}{*}{$\begin{array}{c}\text { Vogal tônica } \\
\text { (oral / nasal / } \\
\text { nasalizada) }\end{array}$} & $\begin{array}{c}\text { Alta } \\
\text { homorgânica }\end{array}$ & & & & & 20.3 & 27 & & \\
\hline & $\begin{array}{c}\text { Alta não } \\
\text { homorgânica }\end{array}$ & 50.6 & 87 & .73 & 172 & 66.8 & 348 & .91 & 521 \\
\hline & Não alta & 5.5 & 196 & .29 & $\begin{array}{c}3.54 \\
3\end{array}$ & 12 & 240 & .33 & 1.992 \\
\hline \multirow{3}{*}{$\begin{array}{l}\text { Vogal átona } \\
\text { (oral /nasal / } \\
\text { nasalizada) }\end{array}$} & $\begin{array}{c}\text { Alta } \\
\text { homorgânica }\end{array}$ & 18.9 & 104 & .81 & 550 & 8.7 & 27 & .43 & 309 \\
\hline & $\begin{array}{c}\text { Alta não } \\
\text { homoroânica }\end{array}$ & 15.8 & 29 & .74 & 184 & 18.5 & 72 & .62 & 390 \\
\hline & Não alta & 7.9 & 70 & .31 & 882 & 17.7 & 160 & .51 & 903 \\
\hline
\end{tabular}

Fonte: Rocha (2013).

O modo de articulação das consoantes precedente e subsequente foi selecionado, respectivamente, como segundo e terceiro elementos mais influentes para a elevação de /e o/. No entanto, enquanto a variante [i] é mais frequente sucedendo consoantes líquidas (.53) e nasais (.53), [u] é mais provável seguindo oclusivas (.64) e fricativas (.57):

No ataque da sílaba seguinte, consoantes oclusivas (.73) e nasais (.71) motivam a elevação de /e/, enquanto segmentos nasais (.63) e fricativos (.55) propiciam a mudança de $/ \mathrm{o} /$.

Os dados confirmam que o alçamento, em ambas as amostras, é motivado sobretudo por fatores estruturais, já que grande parte dos condicionamentos selecionados remete ao contexto em que o segmento se insere na palavra. Ainda que alguns se aproximem consideravelmente da neutralidade (.50), mediante os baixos índices de aplicação da regra, sua relevância se destaca. Além disso, a diversidade de contextos influentes sugere a coatuação de fatores e a recorrência de um mesmo item como aspectos que interferem na representatividade de alguns resultados. 


\section{Quadro Comparativo}

Apesar de alguns dos estudos comentados investigarem os três processos e outros focalizarem apenas o confronto entre alçamento e abaixamento ou alçamento e manutenção na pauta pretônica, descartados contextos categóricos/semicategóricos de alçamento, há o predomínio das vogais médias fechadas em todos eles, em ambas as séries. No entanto, o confronto entre os processos de alçamento e abaixamento revela que os falares de Nova Venécia (ES) e Piranga (MG) se comportam, do ponto de vista diatópico, como falares de transição, apresentando maiores índices de vogais abertas, talvez por sua proximidade geográfica com a Bahia, onde elas predominam.

Sintetizando as informações expostas, a Tabela 9 expõe os índices globais de cada um dos estudos descritos, de acordo com as variantes consideradas para o comportamento das vogais médias pretônicas.

Tabela 9 - Índices percentuais das variantes de / e o/ em contexto pretônico em falares da Região Sudeste

\begin{tabular}{|c|c|c|c|c|}
\hline \multirow{2}{*}{\multicolumn{2}{|c|}{ LOCALIDADE/ESTUDO }} & \multirow{2}{*}{$\begin{array}{c}\text { PROCESSOS } \\
\text { CONSIDERADOS }\end{array}$} & $\begin{array}{c}\text { PRETÔNICA } \\
/ \mathrm{E} /\end{array}$ & $\begin{array}{c}\text { PRETÔNICA } \\
/ \mathrm{O} /\end{array}$ \\
\hline & & & Perc. & Perc. \\
\hline \multirow{3}{*}{ ES } & \multirow{3}{*}{$\begin{array}{c}\text { Nova Venécia } \\
\text { Celia (2004) }\end{array}$} & Manutenção & $70 \%$ & $57 \%$ \\
\hline & & Abaixamento & $14 \%$ & $20 \%$ \\
\hline & & Alteamento & $16 \%$ & $23 \%$ \\
\hline \multirow{6}{*}{ MG } & \multirow{3}{*}{$\begin{array}{l}\text { Machacalis } \\
\text { Zona urbana } \\
\text { Almeida (2008) }\end{array}$} & Manutenção & $48 \%$ & $48 \%$ \\
\hline & & Abaixamento & $19 \%$ & $25 \%$ \\
\hline & & Alteamento & $33 \%$ & $27 \%$ \\
\hline & \multirow{3}{*}{$\begin{array}{c}\text { Machacalis } \\
\text { Zona rural } \\
\text { Almeida (2008) }\end{array}$} & Manutenção & $48 \%$ & $49 \%$ \\
\hline & & Abaixamento & $33 \%$ & $27 \%$ \\
\hline & & Alteamento & $19 \%$ & $24 \%$ \\
\hline
\end{tabular}




\begin{tabular}{|c|c|c|c|c|}
\hline \multirow{6}{*}{ MG } & \multirow{3}{*}{$\begin{array}{c}\text { Piranga } \\
\text { Dias (2008) }\end{array}$} & Manutenção & $51 \%$ & $61 \%$ \\
\hline & & Abaixamento & $26 \%$ & $21 \%$ \\
\hline & & Alteamento & $23 \%$ & $17 \%$ \\
\hline & \multirow{3}{*}{$\begin{array}{c}\text { Ouro Branco } \\
\text { Dias (2008) }\end{array}$} & Manutenção & $78 \%$ & $82 \%$ \\
\hline & & Abaixamento & $18 \%$ & $6,3 \%$ \\
\hline & & Alteamento & $3 \%$ & $11 \%$ \\
\hline \multirow{4}{*}{ SP } & \multirow{2}{*}{$\begin{array}{c}\text { São José do Rio } \\
\text { Preto } \\
\text { Silveira (2008) }\end{array}$} & Manutenção & $87 \%$ & $86 \%$ \\
\hline & & Alteamento & $13 \%$ & $14 \%$ \\
\hline & \multirow{2}{*}{$\begin{array}{c}\text { São José do Rio } \\
\text { Preto } \\
\text { Carmo (2009) }\end{array}$} & Manutenção & $84 \%$ & $90 \%$ \\
\hline & & Alteamento & $16 \%$ & $10 \%$ \\
\hline \multirow{6}{*}{ RJ } & \multirow{3}{*}{$\begin{array}{l}\text { Rio de Janeiro } \\
\text { Yacovenco (1993) }\end{array}$} & Manutenção & $64.3 \%$ & $66.3 \%$ \\
\hline & & Alteamento & $31.8 \%$ & $29.5 \%$ \\
\hline & & Abaixamento & $3.9 \%$ & $4.2 \%$ \\
\hline & \multirow{3}{*}{$\begin{array}{c}\text { Nova Iguaçu } \\
\text { Rocha (2013) }\end{array}$} & Manutenção & $84 \%$ & $78.3 \%$ \\
\hline & & Alteamento & $15.2 \%$ & $20.6 \%$ \\
\hline & & Abaixamento & $0.8 \%$ & $1.1 \%$ \\
\hline
\end{tabular}

Fonte: As autoras.

\section{À Guisa de Conclusão}

Este trabalho objetivou fornecer um panorama geo-sociolinguístico da distribuição das variantes de /e o/ em contexto pretônico na Região Sudeste do país. Com base nas análises comentadas, podem-se apresentar algumas conclusões/considerações gerais de natureza extra e intralinguística.

(a) Nos falares considerados, predominam as variantes [e o], embora com índices mais representativos em uns dialetos do que em outros. Atuam, no entanto, em todos eles, os processos de harmonização e redução vocálicas;

(b) Do ponto de vista diatópico, observam-se aspectos divergentes que demonstram a maior complexidade da área geográfica mineira e, provavelmente da capixaba, frente às do Rio de Janeiro e de São Paulo, 
sugerindo a existência de diferentes áreas linguísticas, sobretudo no que tange ao primeiro dos estados mencionados.

O elemento diferenciador em relação à fala dessas localidades é a frequência das variantes médio- baixas. Como indica a Figura 5, em duas localidades de Minas Gerais (Machacalis e Piranga), [ $\varepsilon$ o] atingem índices entre $19 \%$ e 33\%, e, no Espírito Santo (Nova Venécia), entre 14\% e 20\%. Já na área metropolitana de Belo Horizonte (Ouro Branco), os índices ficam entre $3 \%$ e $11 \%$, caindo drasticamente no Rio de Janeiro (na fala carioca culta e na de Nova Iguaçu, respectivamente, $3,9 \%$ e $0,8 \%$ para $[\varepsilon]$ e $4,2 \%$ e $1,1 \%$ para [0]), circunscrevendo-se a determinados itens lexicais. Por fim, em São Paulo (São José do Rio Preto), essas variantes não são registradas.

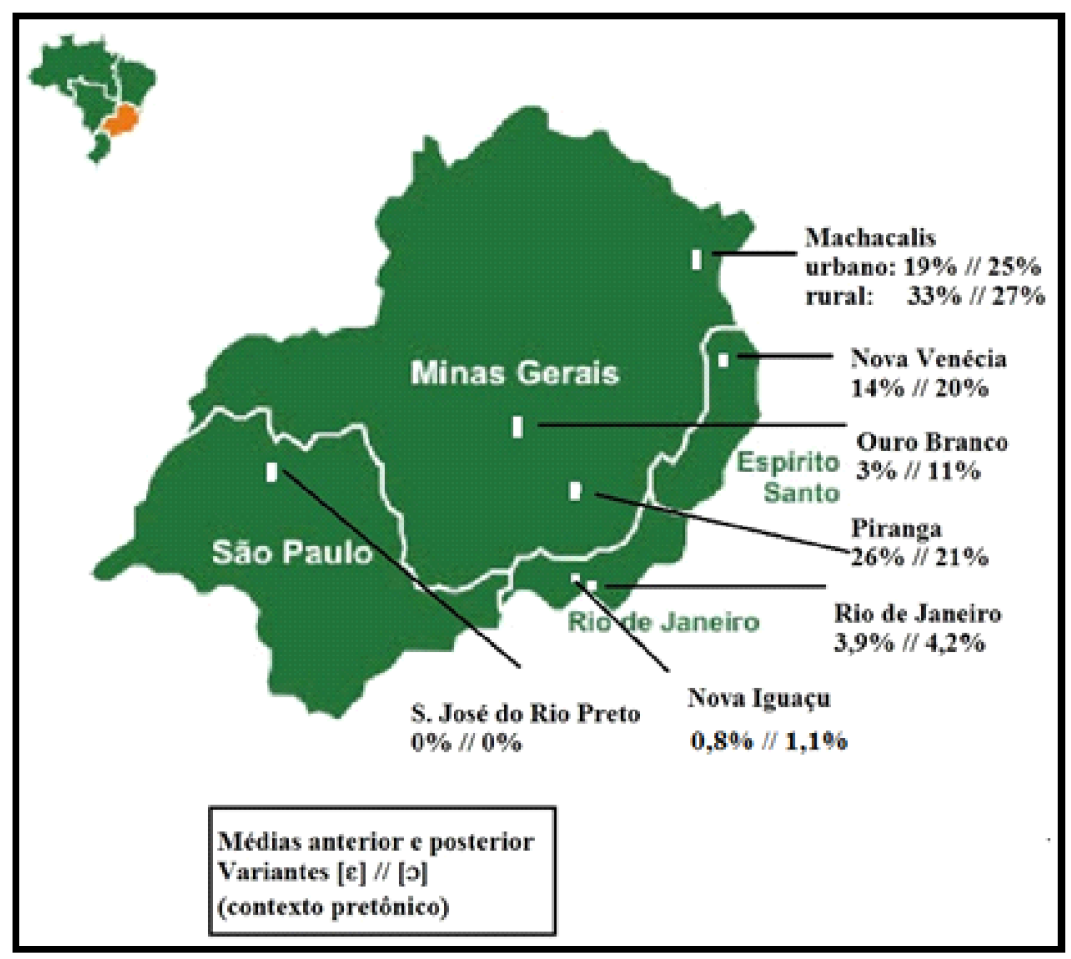

Fonte: Adaptado de <http:/ / migre.me/qJwBp> .

Figura 5 - Incidência das variantes $\left[\begin{array}{ll}\varepsilon & 0\end{array}\right]$ pretônicas em falares da Região Sudeste 
(c) Na localidade de Machacalis, em que se focalizou a zona urbana frente à rural, os índices referentes à manutenção, ao alteamento e ao abaixamento de /e o/ demonstraram as mesmas tendências, permitindo inferir que essas duas variáveis linguísticas não estão sujeitas a julgamentos de valor que, em relação a outras variáveis, opõem variantes estigmatizadas a variantes de prestígio;

(d) Do ponto de vista social, verifica-se, em alguns falares, uma maior incidência de variantes altas na fala dos indivíduos mais velhos, o que indica que o alteamento, que vem se mantendo estável ao longo do tempo, parece apresentar sinais de regressão, como já apontara Bisol (1981), no que respeita à fala do Rio Grande do Sul. Por outro lado, fatores vinculados ao sexo e ao nível de escolaridade podem ser relevantes a depender das comunidades de fala consideradas.

(e) Do ponto de vista estrutural, fica evidente a relevância: (i) da natureza da vogal subsequente (tônica ou pretônica) para a implementação do processo de harmonização vocálica, quer se trate de alteamento, quer se trate de abaixamento; e (ii) do ponto e do modo de articulação das consoantes adjacentes para a atuação da redução vocálica, embora nos dois casos coatuem outras variáveis para a implementação dessas regras;

(f) Apesar de as consoantes adjacentes se mostrarem relevantes para o processo de redução vocálica, os segmentos que podem atuar para o alteamento não coincidem em todas as comunidades, pressupondo a existência de fortes motivações de natureza lexical para a ocorrência do processo.

\section{Referências}

ALMEIDA, L. F. A variação das vogais médias pretônicas na cidade mineira de Machacalis. 2008. Dissertação (Mestrado em Linguística) - Universidade Federal de Minas Gerais, Belo Horizonte.

ALVES, M. M. As vogais médias em posição pretônica nos nomes no dialeto de Belo Horizonte: estudo da variação à luz da Teoria da Otimalidade. 2008. Tese (Doutorado em Linguística) - Universidade Federal de Minas Gerais, Belo Horizonte. 
BISOL, L. Harmonização vocálica, uma regra variável. 1981. Tese (Doutorado em Linguística) - Universidade Federal do Rio de Janeiro, Rio de Janeiro.

CALLOU, D.; LEITE, Y; COUTINHO, L. Elevação e abaixamento das vogais pretônicas no Rio de Janeiro. Organon, Porto Alegre, n. 18, p. 71-78, 1991.

CAMARA JR, J. M. Estrutura da lingua portuguesa. Rio de Janeiro: Vozes, 1970.

CARMO, M. N. As vogais médias pretônicas dos verbos na fala culta do interior paulista. 2009. Dissertação (Mestrado em Linguística) - Universidade Estadual Paulista "Júlio de Mesquita Filho", São José do Rio Preto.

CELIA, G. F. As vogais médias pretônicas na fala culta de Nova Venécia. 2004. Dissertação (Mestrado em Linguística) - Universidade Estadual de Campinas, Campinas.

COLLISCHONN, G.; SCHWINDT, L. C. Harmonia vocálica no sistema verbal do português do sul do Brasil. Estudos de Fonologia e de Morfologia, Porto Alegre, v. 18, n. 36, p. 73-82, 2004.

DIAS, M. R. A variação das vogais médias pretônicas no falar dos mineiros de Piranga e Ouro Branco. 2008. Dissertação (Mestrado em Estudos Linguísticos) - Universidade Federal de Minas Gerais, Belo Horizonte.

GUIMARÃES, R. V. M. Variação das vogais médias em posição pretônica nas regiões norte e sul de Minas Gerais: uma abordagem à luz da Teoria da Otimalidade. 2007. 212 p. Dissertação (Mestrado em Estudos Linguísticos) - Universidade Federal de Minas Gerais, Belo Horizonte.

OLIVEIRA, M. A. The neogrammarian controversy revisited. International Journal of the sociology of language, Berlim, v. 89, p. 93-105, 1991.

OLIVEIRA, M. A. Aspectos da difusão lexical. Revista de Estudos da Linguagem, Belo Horizonte, n. 1, p. 31-41, 1992. 
OLIVEIRA, M. A. A controvérsia neogramática reconsiderada. In: ALBANO E. et al. (Orgs.). Saudades da língua: a lingüística e os 25 anos do Instituto de Estudos da Linguagem da Unicamp. Campinas: Mercado Letras, 2003.

OLIVEIRA, M. A. Variação lingüística e teoria fonológica. In: ENCONTRO NACIONAL DA ANPOLL, 21., 2006, São Paulo. Apresentação de trabalho.

ROCHA, F. de M. V. O comportamento das vogais médias pretônicas na fala de Nova Iguaçu. 2013. Dissertação (Mestrado em Letras Vernáculas) Universidade Federal do Rio de Janeiro, Rio de Janeiro.

SILVEIRA, A. A. M. As vogais pretônicas na fala culta do noroeste paulista. 2008. Dissertação (Mestrado em Estudos Linguísticos) - Universidade Estadual Paulista, São José do Rio Preto.

VIANA, V. F. As vogais médias pretônicas em Pará de Minas: um caso de variação lingüística. 2008. Dissertação (Mestrado em Linguística e Língua Portuguesa) - Pontifícia Universidade Católica de Minas Gerais, Belo Horizonte.

VIEGAS, M. C. O alçamento de vogais médias pretônicas e os itens lexicais. 2001. Tese (Doutorado em Letras - Estudos Linguísticos) - Universidade Federal de Minas Gerais, Belo Horizonte.

VIEGAS, M. do C.; VEADO, R. M. A. Alçamento de vogais pretônicas. In: VEADO, R.; ALVARENGA, D. (Orgs.). Ensaios de Lingüistica, Belo Horizonte, n. 7, p. 53-70, 1982.

YACOVENCO, L. C. As vogais médias pretônicas no falar culto carioca. 1993. Dissertação (Mestrado em Língua Portuguesa) - Universidade Federal do Rio de Janeiro, Rio de Janeiro. 